\title{
New Phosphate-Sulfates with NZP Structure
}

\author{
D. O. Savinykh ${ }^{a}$, *, S. A. Khainakov ${ }^{b}$, A. I. Orlova ${ }^{a}$, and S. Garcia-Granda ${ }^{b}$ \\ ${ }^{a}$ Lobachevsky State University, Nizhny Novgorod, 603950 Russia \\ ${ }^{b}$ University of Oviedo, Oviedo, 33003 Spain \\ *e-mail: savinyhdmitry@mail.ru
}

\section{Abstract}

$\mathrm{NaZr}_{2-x} \mathrm{~B}_{x}\left(\mathrm{PO}_{4}\right)_{3-2 x}\left(\mathrm{SO}_{4}\right)_{2 x}(0 \leq x \leq 1.25, \mathrm{~B}=\mathrm{Mg}, \mathrm{Co}, \mathrm{Ni}, \mathrm{Cu}, \mathrm{Zn})$, and $\mathrm{NaZr}_{2-}$ ${ }_{x} \mathrm{R}_{x}\left(\mathrm{PO}_{4}\right)_{3-x}\left(\mathrm{SO}_{4}\right)_{x}(0 \leq x \leq 1.25, \mathrm{R}=\mathrm{Al}, \mathrm{Fe})$ phosphate-sulfates series have been prepared by a sol-gel process. These compounds belong to the $\mathrm{NaZr}_{2}\left(\mathrm{PO}_{4}\right)_{3}(\mathrm{NZP})$ structure family and crystallize in hexagonal crystal system, space group $R \overline{3} c$. Limited solid solution series were found to exist; their formation temperatures and thermal stability limits were determined. Particle sizes as determined by microstructure observation were $50-200 \mathrm{~nm}$, and for $\mathrm{Cu}$ - and $\mathrm{Zn}$-containing samples, 200-500 $\mathrm{nm}$. The thermal expansion of phosphate-sulfate $\mathrm{NaZr}_{1.25} \mathrm{Cu}_{0.75}\left(\mathrm{PO}_{4}\right)_{1.5}\left(\mathrm{SO}_{4}\right)_{1.5}$ was studied in the range $25-700^{\circ} \mathrm{C}$. Thermal expansion coefficients and thermal expansion anisotropy were found to be $\alpha_{\mathrm{a}}=-$ $5.40 \times 10^{-6}{ }^{\circ} \mathrm{C}^{-1}, \alpha_{\mathrm{c}}=18.88 \times 10^{-6}{ }^{\circ} \mathrm{C}^{-1}, \alpha_{\text {avg }}=2.69 \times 10^{-6}{ }^{\circ} \mathrm{C}^{-1}$, and $\Delta \alpha=24.28 \times$ $10^{-6}{ }^{\circ} \mathrm{C}^{-1}$.

\section{INTRODUCTION}

Design of heat-stress-resistant materials is an important and topical problem of modern materials science [1-5]. These materials can be used in the creation of products for nuclear and space technologies, ceramic pigments, in nuclear technologies for inert fuel matrices and matrices for disposal of radioactive waste, as well as for other applications. Their important properties are thermal stability over a wide temperature range, high thermal conductivity, and no deformation caused by thermal expansion that can lead to destruction.

Of these materials, of interest are ceramics based on salt and oxide inorganic compounds. Particular attention should be paid to compounds crystallizing in the $\mathrm{NaZr}_{2}\left(\mathrm{PO}_{4}\right)_{3}$ (NZP) structure type [6, 7]. These compounds are known for their high thermal stability $[2,8]$ and some of them for near-zero thermal expansion attained due to a specific heating behavior of the structure consisting in expansioncontraction in different crystallographic directions [3,9-12]. Not only a low value of the thermal expansion coefficient is important for design of heat "stress" resistant materials, but also low thermal expansion anisotropy is.

The structure of $\mathrm{NaZr}_{2}\left(\mathrm{PO}_{4}\right)_{3}$ and compounds of its family is described by the general crystal-chemical formula $(\mathrm{M} 1)^{\mathrm{VI}}(\mathrm{M} 2)_{3}{ }^{\mathrm{VIII}}\left[\mathrm{L}_{2}\left(\mathrm{XO}_{4}\right)_{3}\right]$, where $\mathrm{L}$ and $\mathrm{M}(\mathrm{M} 1$ and $\mathrm{M} 2$ ) are framework atomic positions and interstitial (extraframework) positions, respectively; VI and VIII denote their coordination surroundings. Positions $\mathrm{M}$ can be occupied completely or partially, or they can remain vacant. They are populated mostly by low-charge and relatively large cations, while the $\left[\mathrm{L}_{2}\left(\mathrm{XO}_{4}\right)_{3}\right]$ framework is built by multicharged cations of small size and negatively charged tetrahedral oxo anions $\mathrm{XO}_{4}$. 
Various isovalent and heterovalent substitutions, which are typical of the NZP structure $[6,7,13,14]$, create the possibility to tune the properties of compounds in the desired way, specifically thermal expansion characteristics.

The thermal expansion model advanced in $[6,10]$ suggests that the heating behavior of such phosphates depends on the nature of the involved cations (their size, charge, and electronegativity), the major contributors being the weakest bonds. The cations in extraframework positions $\mathrm{M}$ and the occupancies of these positions have a greater influence.

The following ways are known to reduce thermal expansion parameters in NZP compounds: (1) to increase the radius of an extraframework cation: here, the crystal-chemical principle runs ahead of the thermal one (the position is already expanded due to the residence of a large cation); (2) to reduce the M (interstitial) site occupancy: thereby, the number of cations responsible for thermal deformation is reduced; and (3) to generate solid solutions based on compounds ofisovalent cations whose axial thermal expansion coefficients have different signs. The implementation of these principles is exemplified in the following phosphates: (1) CsZr ${ }_{2}\left(\mathrm{PO}_{4}\right)_{3}$ [15] and $\mathrm{Ba}_{0.5} \mathrm{FeTa}\left(\mathrm{PO}_{4}\right)_{3}$ [16]; (2) $\mathrm{Al}_{0.5} \mathrm{Nb}_{1.5}\left(\mathrm{PO}_{4}\right)_{3}$ [17] and $\mathrm{Er}_{0.08} \mathrm{Zr}_{0.19} \mathrm{Zr}_{2}\left(\mathrm{PO}_{4}\right)_{3}$ [18]; and (3) $\mathrm{Ca}_{0.25} \mathrm{Sr}_{0.25} \mathrm{Zr}_{2}\left(\mathrm{PO}_{4}\right)_{3}$ [19]. However, there are only few such compounds, and many of the known ones contain high-cost elements (Cs, $\mathrm{Ta}, \mathrm{Nb}$, and lanthanides). Therefore, it is necessary to search for new materials, as well as for new approaches to the design of compounds that are stable under heat "stress" conditions.

This study is concerned with the extension of the first of the above crystalchemical principles, namely, isomorphous substitutions in the cationic and anionic portions of the framework in NZP-related compounds due to doping smaller cations into sites $\mathrm{L}$ and/or $\mathrm{X}$. This doping should reduce the unit cell volume, in particular, extraframework sites $\mathrm{M}$, and thereby enabling $\mathrm{Na}$ and $\mathrm{K}$ cations, which have smaller sizes than Cs, to exert an analogous effect on thermal expansion.

NZP phosphates where site $\mathrm{L}$ is occupied by cations( $\mathrm{Mn}, \mathrm{Co}, \mathrm{Ni}, \mathrm{Al}, \mathrm{Fe}, \mathrm{Ga}, \mathrm{Ti}$, $\mathrm{Ge}, \mathrm{Mo}, \mathrm{Sn}, \mathrm{V}, \mathrm{Nb}, \mathrm{Sb}$, or $\mathrm{Ta}$ ) that have smaller ionic radii compared to $\mathrm{Zr}$ are described in the literature [7]. Thermal expansion was studied for many of them, namely, for $\mathrm{Na}_{2 x} \mathrm{R}_{0.5+x} \mathrm{Nb}_{1.5-x}\left(\mathrm{PO}_{4}\right)_{3}(\mathrm{R}=\mathrm{Al}, \mathrm{Fe} ; 0 \leq x \leq 0.5)$ [17], $\mathrm{Na}_{2} \mathrm{R}_{1.5} \mathrm{C}_{0.5}\left(\mathrm{PO}_{4}\right)_{3}$ $(\mathrm{R}=\mathrm{Al}, \mathrm{Cr}, \mathrm{Fe} ; \mathrm{C}=\mathrm{Nb}, \mathrm{Ta})$ [20], $\mathrm{Ca}_{0.5} \mathrm{SbR}\left(\mathrm{PO}_{4}\right)_{3}(\mathrm{R}=\mathrm{Al}, \mathrm{Cr}, \mathrm{Fe})$ [21], $\mathrm{Mn}_{0.5} \mathrm{SbR}\left(\mathrm{PO}_{4}\right)_{3}(\mathrm{R}=\mathrm{Al}, \mathrm{Cr}, \mathrm{Fe})$ [22], $\mathrm{BRSn}\left(\mathrm{PO}_{4}\right)_{3}(\mathrm{~B}=\mathrm{Ca}, \mathrm{Sr} ; \mathrm{R}=\mathrm{Cr}, \mathrm{Fe})$ [23], $\mathrm{B}_{0.5} \mathrm{FeTa}\left(\mathrm{PO}_{4}\right)_{3}(\mathrm{~B}=\mathrm{Ca}, \mathrm{Sr}, \mathrm{Ba})$ [16], $\mathrm{NaGe}_{2-x} \mathrm{Tix} x\left(\mathrm{PO}_{4}\right)_{3}(0.25 \leq x \leq 1)$ [24], $\mathrm{NaM}_{2}\left(\mathrm{PO}_{4}\right)_{3}$ and $\mathrm{NbM}\left(\mathrm{PO}_{4}\right)_{3}(\mathrm{M}=\mathrm{Ti}, \mathrm{Zr}, \mathrm{Sn}, \mathrm{Hf})$ [25], $\mathrm{NaTi}_{2}\left(\mathrm{PO}_{4}\right)_{3}$ and $\mathrm{Sr}_{0.5} \mathrm{Ti}_{2}\left(\mathrm{PO}_{4}\right)_{3}$ [26], $\mathrm{La}_{0.33} \mathrm{Ti}_{2}\left(\mathrm{PO}_{4}\right)_{3}$ [27], $\mathrm{LiGe}_{2}\left(\mathrm{PO}_{4}\right)_{3}$ [28], $\mathrm{KGe}_{2}\left(\mathrm{PO}_{4}\right)_{3}$ [29], and $\mathrm{Na}_{1-x} \mathrm{Nb}_{x} \mathrm{Zr}_{2-x}\left(\mathrm{PO}_{4}\right)_{3}(0 \leq x \leq 1)[30]$.

Of the elements that form tetrahedral oxo anions( $\mathrm{Si}, \mathrm{Ge}, \mathrm{As}, \mathrm{V}, \mathrm{Nb}, \mathrm{S}, \mathrm{Se} \mathrm{Mo}$, and $\mathrm{W}$ ), only sulfur has a smaller ionic radius than the phosphorus ionic radius. Zirconium phosphate-sulfate $\mathrm{Zr}_{2}\left(\mathrm{PO}_{4}\right)_{2}\left(\mathrm{SO}_{4}\right)$ crystallizing in NZP structure has been studied [31]. Compounds of the same composition having another structure (scandium tungstate type) were described $[32,33]$. Thermal expansion data were reported for phosphate-sulfates $\mathrm{NaFeZr}\left(\mathrm{PO}_{4}\right)_{2}\left(\mathrm{SO}_{4}\right)$ and 
$\mathrm{Pb}_{0.66} \mathrm{FeZr}\left(\mathrm{PO}_{4}\right)_{2.33}\left(\mathrm{SO}_{4}\right)_{0.66}$ [34]. Thus, there are only few pieces of data on the thermal expansion of mixed NZP phosphate-sulfates.

In materials based on sulfur-containing NZP compounds, however, the first of the above-considered principles of adjusting thermal expansion parameters must be expected for cations at sites $\mathrm{M}$ having smallersizes compared to the cesium cation size. This opens a way to expand the number of compounds with small and adjustable thermal expansion, in addition, being more environmentally friendly (with cesium being replaced by other alkali cations).

The goals of this study were to prepare and characterize sulfur-containing NZP compounds and to study the effect on the unit cell volume caused by a reduction in cation size at anionic framework site $\mathrm{X}$ upon substitution of sulfur for phosphorus. For balancing the change in charge of the anionic framework portion, we had to dope the cationic framework portion with $\mathrm{Mg}, \mathrm{Co}, \mathrm{Ni}, \mathrm{Cu}, \mathrm{Zn}, \mathrm{Al}$, or Fe cations, whose ionic radii are smaller than, or are comparable with, the $\mathrm{Zr}$ ionic radius $(r$ ranging from 0.053 to $0.074 \mathrm{~nm}$ ). With this, the principle of heterovalent isomorphism, namely, the replacement of cation-cation and cation- anion pairs with equal total charges, should be implemented.

The expected decrease in unit cell volume and, thereby, in extraframework site $\mathrm{M}$ volume should promote the implementation of the outperforming role of the crystal-chemical principle in comparison with the thermal one for cations smaller than cesium, for example, for sodium. We intended to check whether this principle would operate, namely, whether the thermal expansion characteristics would decrease in response to decreasing unit cell volume, using one of the prepared phosphate-sulfates.

\section{EXPERIMENTAL}

Subjects. We chose to study the phosphate-sulfates that constitute the following series: (1) $\mathrm{NaZr}_{2-x} \mathrm{~B}_{x}\left(\mathrm{PO}_{4}\right)_{3-2 x}\left(\mathrm{SO}_{4}\right)_{2 x}$, where $0 \leq x \leq 1.25$, and $\mathrm{B}=\mathrm{Mg}$, $\mathrm{Co}, \mathrm{Ni}, \mathrm{Cu}, \mathrm{Zn}$; and (2) $\mathrm{NaZr}_{2-x} \mathrm{R}_{x}\left(\mathrm{PO}_{4}\right)_{3-x}\left(\mathrm{SO}_{4}\right)_{x}$, where $0 \leq x \leq 1.25$, and $\mathrm{R}=\mathrm{Al}$, $\mathrm{Fe}$. Thermal expansion was studied on one of the compounds prepared, namely, $\mathrm{NaZr}_{1.25} \mathrm{Cu}_{0.75}\left(\mathrm{PO}_{4}\right)_{1.5}\left(\mathrm{SO}_{4}\right)_{1.5}$.

Synthesis of the compounds was carried out by a sol-gel process. Solutions of metal nitrates or chlorides and powdery zirconium oxychloride were mixed. To the thus-prepared solution, an ammonium dihydrophosphate solution was added drop by drop under continuous stirring. A gel was formed in this way. The gel was added with dilute sulfuric acid and then with ethanol $(\sim 5 \mathrm{~mL}$ per final product gram). The reagents were mixed in stoichiometric ratios. After a short-time stirring (lasting up to $5 \mathrm{~min}$ ), the gel was dried at $90^{\circ} \mathrm{C}$ for $24 \mathrm{~h}$. The thus-prepared powder was thermostated at $500,700,800,900$, and $1000^{\circ} \mathrm{C}$ for $20 \mathrm{~h}$ at every step with intermittent dispersion with an agate mortar and a pestle and XRD monitoring.

Methods. Microstructure was studied by scanning electron microscopy (SEM) using JEOL JSM-661OLV. X-ray powder diffraction (XRD) patterns and hightemperature X-ray diffraction spectra were recorded on a Shimadzu LabX XRD 6000 diffractometer using $\mathrm{Cu} K \alpha$ radiation $(\lambda=1.54178 \AA)$. X-ray diffraction patterns were recorded in the $2 \theta$ angle range from 10.00 to $50.00 \mathrm{deg}$ in $0.02 \mathrm{deg}$ 
steps at a speed of $2 \mathrm{deg} / \mathrm{min}$. High-temperature X-ray diffraction spectra were recorded at $25-700^{\circ} \mathrm{C}$ on an HA 1001 SHIMADZU unit. Unit cell parameters were refined in the CELREF program [35]. A differential scanning calorimetry (DSC) diagram was recorded on Setaram LABSYS DSC 1600 at temperatures from 25 to $1000^{\circ} \mathrm{C}$ at a heating rate of $10 \mathrm{~K} / \mathrm{min}$. Thermogravimetric (TG) curves were recorded on a TGA/SDTA 851e Mettler Toledo thermal analyzer at temperatures from 25 to $1000^{\circ} \mathrm{C}$ at a heating rate of $10 \mathrm{~K} / \mathrm{min}$.

\section{RESULTS AND DISCUSSION}

The compounds prepared were polycrystalline powders whose color depended on composition: the powders containing $\mathrm{Mg}, \mathrm{Zn}$, and $\mathrm{Al}$ were colorless; the powders containing $\mathrm{Co}$ were blue; those containing $\mathrm{Ni}$ and $\mathrm{Cu}$ were green; and those with Fe were orange.

They have a homogeneous microstructure as observed by SEM (Figs. 1, 2). Crystallite sizes for the $\mathrm{Mg}-, \mathrm{Co}_{-}, \mathrm{Ni}-, \mathrm{Al}-$, and $\mathrm{Fe}$-containing samples are 50-200 $\mathrm{nm}$; the compounds containing $\mathrm{Cu}$ and $\mathrm{Zn}$ have greater particle sizes: $200-500 \mathrm{~nm}$.

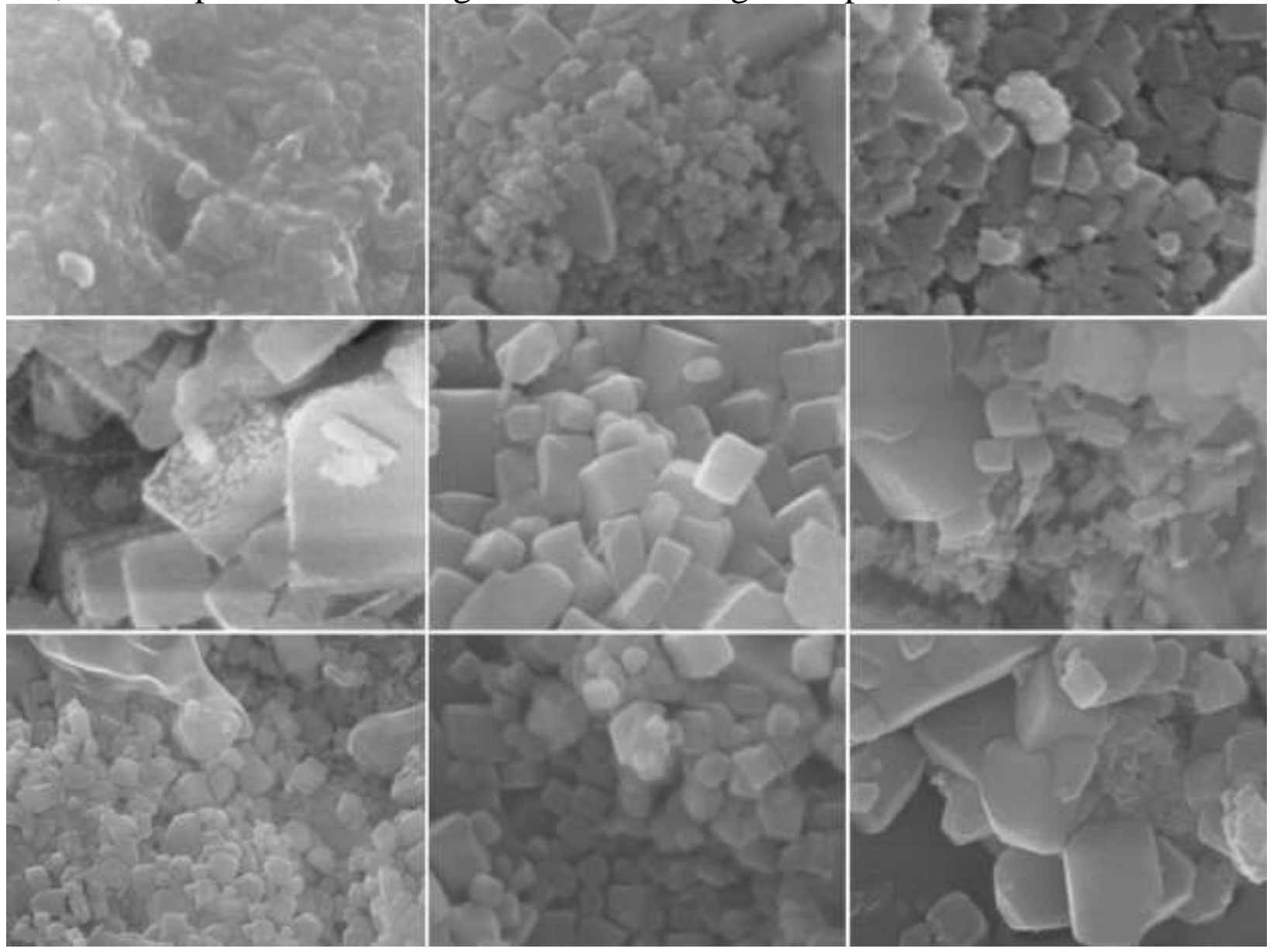

Fig. 1. SEM data. Phosphate-sulfates: $\mathrm{NaZr}_{2-x} \mathrm{~B}_{x}\left(\mathrm{PO}_{4}\right)_{3-2 x}\left(\mathrm{SO}_{4}\right)_{2 x}$ where (a) $\mathrm{B}=$ $\mathrm{Mg}, x=0.5$; (b) B $=\mathrm{Co}, x=0.5$; (c) B = Ni, $x=0.5$; (d-f) B $=\mathrm{Cu}$, (d) $x=0.5$, (e) $x$ $=0.75$, and (f) $x=1$; and (g-i) $\mathrm{B}=\mathrm{Zn},(\mathrm{g}) x=0.5$, (h) $x=0.75$, and (i) $x=1$ after annealing at $700^{\circ} \mathrm{C}$.

Figure 3 shows XRD data for phosphate-sulfates of doubly charged cations with the ratio $\mathrm{PO}_{4}: \mathrm{SO}_{4}=1: 1$ after heating in the course of synthesis at various 
temperatures. Figure 4 shows similar data for the Aland Fe-containing phosphatesulfates where $\mathrm{PO}_{4}: \mathrm{SO}_{4}=5: 1$.

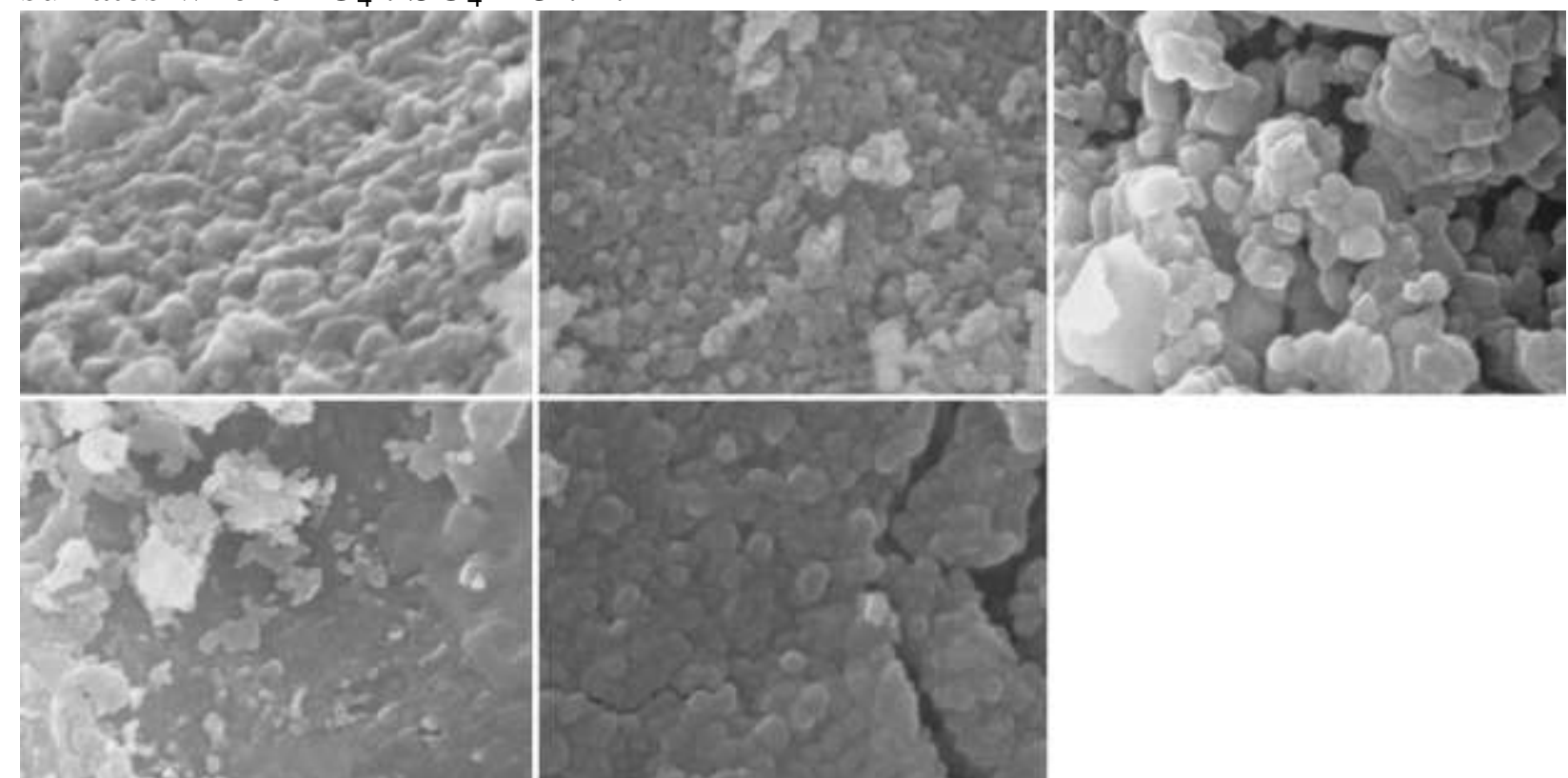

Fig. 2. SEM data. Phosphate-sulfates: $\mathrm{NaZr}_{2-x} \mathrm{R}_{x}\left(\mathrm{PO}_{4}\right)_{3-x}\left(\mathrm{SO}_{4}\right)_{x}$ where (a) $\mathrm{R}=\mathrm{Al}, x$ $=0.5$; (b-e) $\mathrm{R}=\mathrm{Fe}$, (b) $x=0.5$, (c) $x=0.75$, (d) $x=1$, and (e) $x=1.25$ after annealing at $700^{\circ} \mathrm{C}$.

The NZP phase in all compounds and solid solutions of the series under consideration was formed at $700^{\circ} \mathrm{C}$ as shown by XRD. Single-phase products in a system with doubly charged cations were prepared only for $\mathrm{Cu}$ and $\mathrm{Zn}$ compounds. In the compounds with triply charged cations at 700 and $800^{\circ} \mathrm{C}$, there are virtually no foreign phases. As the isothermal exposure temperature increased, the reflection intensity in $\mathrm{Co}$ and $\mathrm{Zn}$-containing samples was reduced. For the $\mathrm{Mg}-, \mathrm{Ni}-$, and $\mathrm{Cu}-$ containing samples, the highest reflection intensity was observed after annealing at $800^{\circ} \mathrm{C}$; for the $\mathrm{Al}$ - and Fe-containing samples, after annealing at $900^{\circ} \mathrm{C}$. However, the content of foreign phases in samples increased in response to rise in heating temperature for compounds of all series; this can arise from partial decomposition of the prepared phosphate- sulfates, possibly with removal of a sulfate group to yield a new phase, which is also NZP. From a comparison of XRD reflection intensity data, one can conclude that the phosphate-sulfates samples doped with tervalent cations are more stable thermally than the phosphate-sulfates doped with divalent cations.

For having a deeper insight into phase formation and suggested decomposition, we recorded DSC diagrams for the precursors that were used to prepare phosphatesulfates $\mathrm{NaZr}_{1.25} \mathrm{Ni}_{0.75}\left(\mathrm{PO}_{4}\right)_{1.5}\left(\mathrm{SO}_{4}\right)_{1.5} \quad\left(\mathrm{PO}_{4}: \mathrm{SO}_{4}=1: 1\right)$ and $\mathrm{NaZr}_{1.5} \mathrm{Fe}_{0.5}\left(\mathrm{PO}_{4}\right)_{2.5}\left(\mathrm{SO}_{4}\right)_{0.5}\left(\mathrm{PO}_{4}: \mathrm{SO}_{4}=5: 1\right)$. The gel obtained by mixing the reagents for preparing samples of indicated compositions was dried at $90^{\circ} \mathrm{C}$ for 24 $\mathrm{h}$ and then kept at $200^{\circ} \mathrm{C}$ for a short time (for about $2 \mathrm{~h}$ ). The two phosphatesulfates have similar DSC curves (Fig. 5). The diagrams show features at $150-200^{\circ} \mathrm{C}$ due to the elimination of remnant crystal water from the samples, at $400^{\circ} \mathrm{C}$ due to the decomposition of the initial reagents, at $600^{\circ} \mathrm{C}$ due to the solidphase reaction of target products, and at $750-800^{\circ} \mathrm{C}$ due to the decomposition of 
phosphate-sulfates. These results correlate with the XRD data on phase formation and decomposition temperatures.

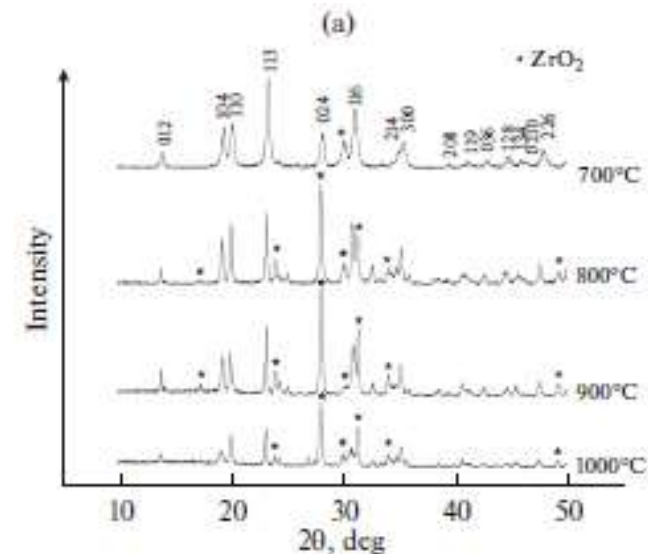

(c)

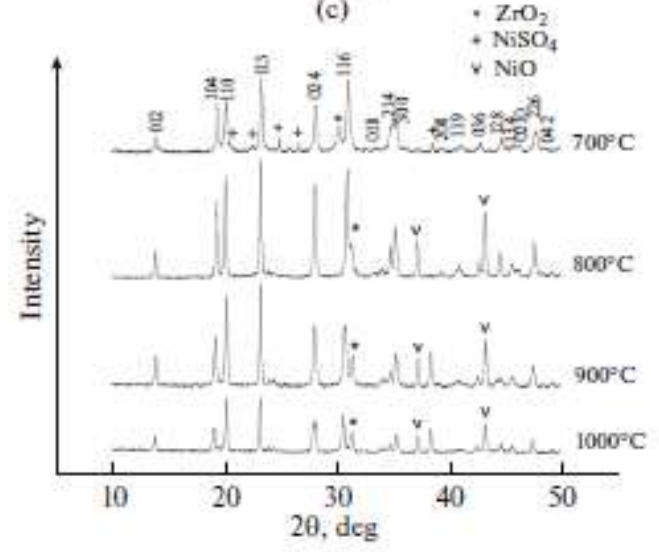

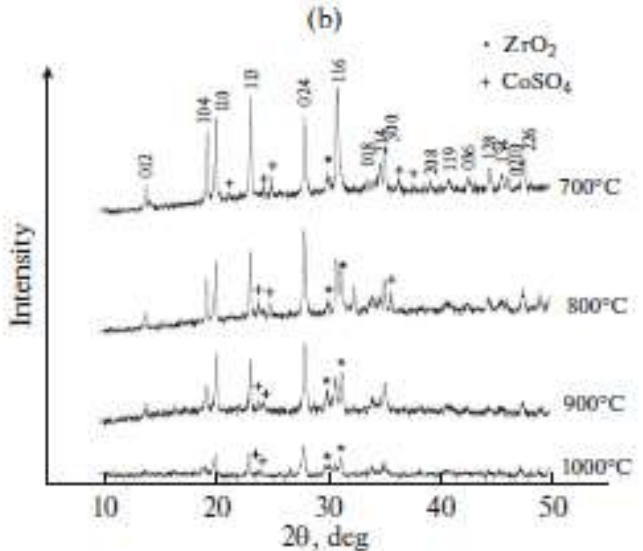

(d)

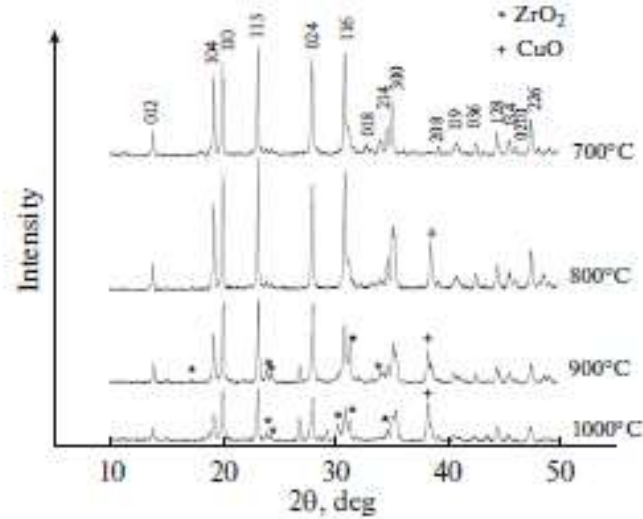

(c)

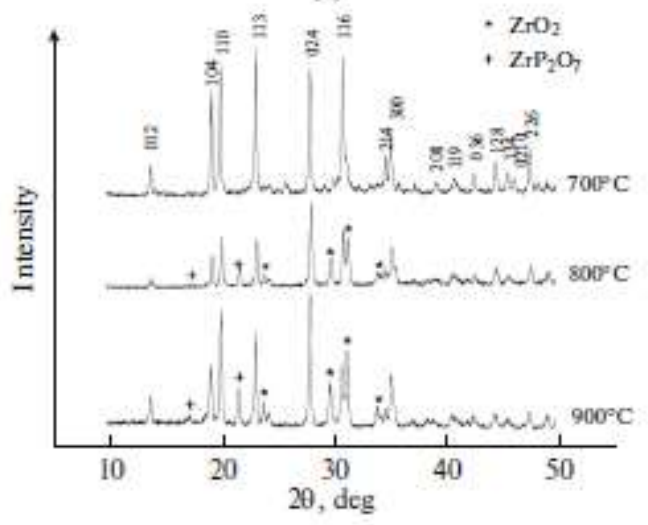

Fig. 3. XRD data. Phosphate-sulfates: $\mathrm{NaZr}_{1.25} \mathrm{~B}_{0.75}\left(\mathrm{PO}_{4}\right)_{1.5}\left(\mathrm{SO}_{4}\right)_{1.5}$ where $\mathrm{B}=(\mathrm{a})$ $\mathrm{Mg}$, (b) $\mathrm{Co}$, (c) $\mathrm{Ni}$, (d) $\mathrm{Cu}$, and (e) Zn after annealing at temperatures of 700 to $1000^{\circ} \mathrm{C}$.

Thermogravimetric experiments (Fig. 6) show that the heating of $\mathrm{NaZr}_{1.5} \mathrm{Mg}_{0.5}\left(\mathrm{PO}_{4}\right)_{2}\left(\mathrm{SO}_{4}\right), \quad \mathrm{NaZr}_{1.5} \mathrm{Co}_{0.5}\left(\mathrm{PO}_{4}\right)_{2}\left(\mathrm{SO}_{4}\right), \quad \mathrm{NaZr}_{1.25} \mathrm{Cu}_{0.75}\left(\mathrm{PO}_{4}\right)_{1.5}\left(\mathrm{SO}_{4}\right)_{1.5}$, and $\mathrm{NaZrCu}\left(\mathrm{PO}_{4}\right)\left(\mathrm{SO}_{4}\right)_{2}$ samples at temperatures in the range $160-270^{\circ} \mathrm{C}$ was accompanied with a weight loss, likely due to water elimination (the presence of crystal hydrates can be suggested). Samples where $\mathrm{PO}_{4}: \mathrm{SO}_{4} \geq 2: 1$ decomposed at higher temperatures $\left(T>820^{\circ} \mathrm{C}\right)$ than $\mathrm{PO}_{4}: \mathrm{SO}_{4}<2: 1$ samples $\left(T>720^{\circ} \mathrm{C}\right)$, also in agreement with XRD data. 

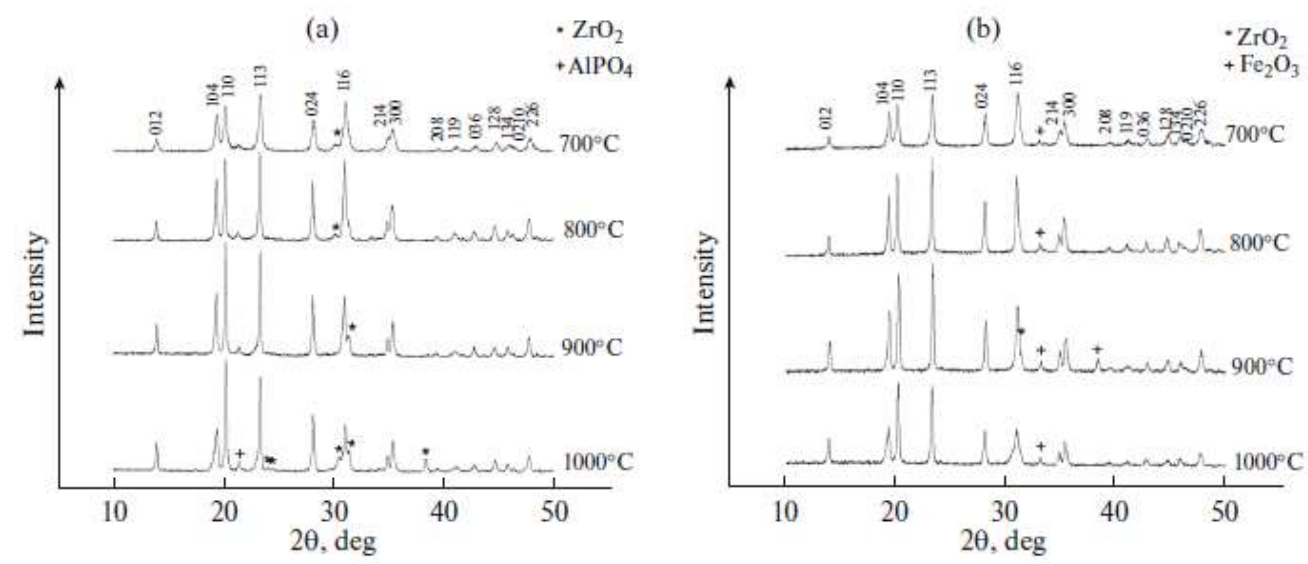

Fig. 4. XRD data. Phosphate-sulfates $\mathrm{NaZr}_{1.5} \mathrm{R}_{0.5}\left(\mathrm{PO}_{4}\right)_{2.5}\left(\mathrm{SO}_{4}\right)_{0.5}$ where $\mathrm{R}=(\mathrm{a})$ $\mathrm{Al}$ and (b) Fe after annealingat temperatures of 700 to $1000^{\circ} \mathrm{C}$.
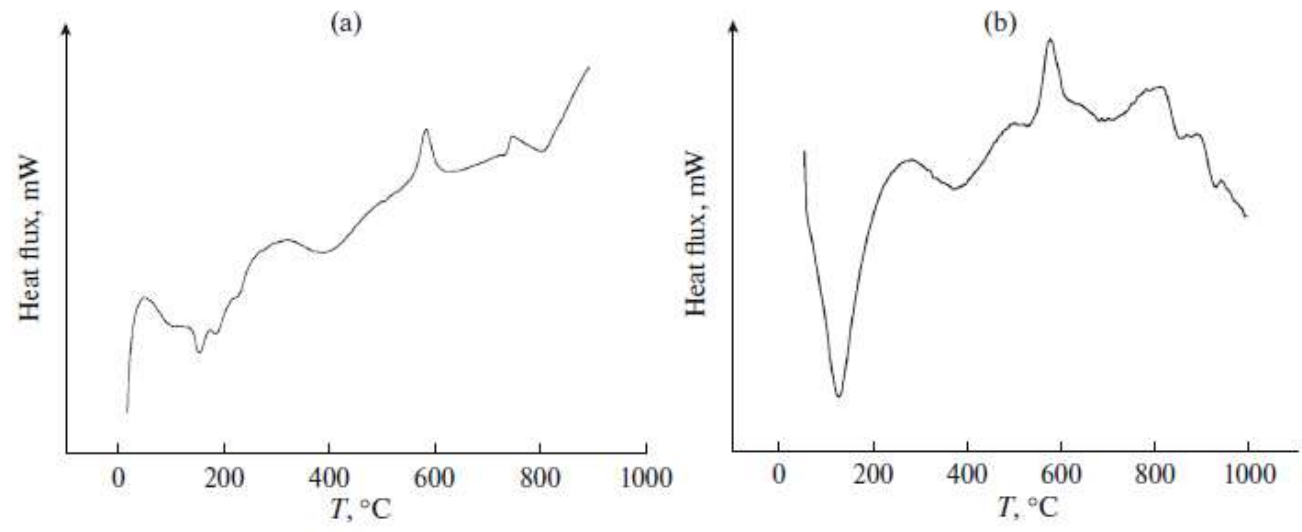

Fig. 5. DSC data. Precursors of phosphate-sulfates: $\mathrm{NaNi}_{0.75} \mathrm{Zr}_{1.25}\left(\mathrm{PO}_{4}\right)_{1.5}\left(\mathrm{SO}_{4}\right)_{1.5}$ and (b) $\mathrm{NaZr}_{1.5} \mathrm{Fe}_{0.5}\left(\mathrm{PO}_{4}\right)_{2.5}\left(\mathrm{SO}_{4}\right)_{0.5}$.

(a)

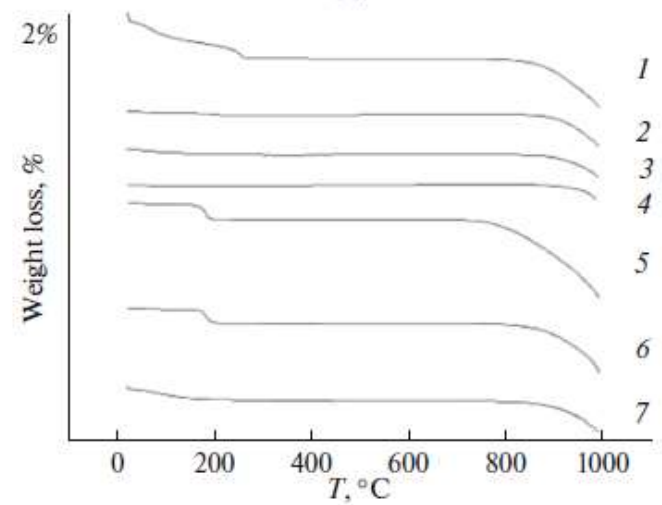

(b)

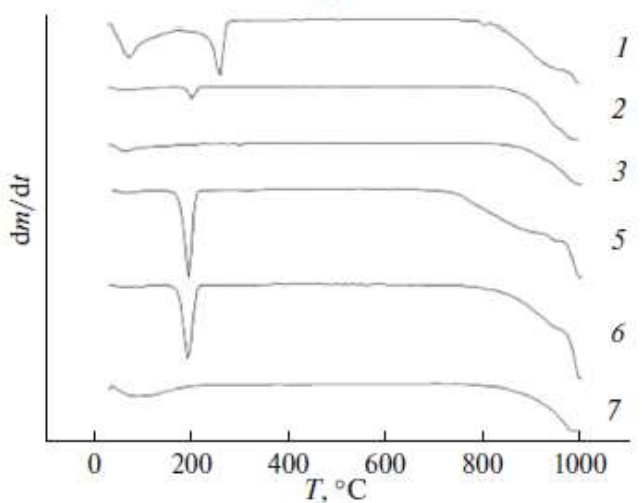

Fig. 6. (a) TG and (b) DTG data. Phosphate-sulfates: $\mathrm{NaZr}_{2-x} \mathrm{~B}_{x}\left(\mathrm{PO}_{4}\right)_{3-2 x}\left(\mathrm{SO}_{4}\right)_{2 x}$ where (1) B = Mg, $x=0.5$; (2) Co, $x=0.5$; (3) Ni, $x=0.5$; (4-6) $\mathrm{B}=\mathrm{Cu}, x=(4)$ 0.5 , (5) $x=0.75$, and (6) $x=1$; and $\mathrm{NaZr}_{2-x} \mathrm{R}_{x}\left(\mathrm{PO}_{4}\right)_{3-x}\left(\mathrm{SO}_{4}\right)_{x}$ where (7) $\mathrm{R}=\mathrm{Al}, x=$ 0.5 .

The existence ranges of solid solutions as determined from XRD of samples annealed at $700^{\circ} \mathrm{C}$ (Figs. 7, 8) were as follows for the following series: for $\mathrm{NaZr}_{2-x} \mathrm{Mg}_{x}\left(\mathrm{PO}_{4}\right)_{3-2 x}\left(\mathrm{SO}_{4}\right)_{2 x}, 0 \leq x \leq 0.75$ (for $x_{\max }=0.75, \mathrm{PO}_{4}: \mathrm{SO}_{4}=1: 1$ ); for 
$\mathrm{NaZr}_{2-x} \mathrm{Cu}_{x}\left(\mathrm{PO}_{4}\right)_{3-2 x}\left(\mathrm{SO}_{4}\right)_{2 x}, 0 \leq x \leq 1$ (for $x_{\max }=1, \mathrm{PO}_{4}: \mathrm{SO}_{4}=1: 2$ ); for $\mathrm{NaZr}_{2-}$ ${ }_{x} \mathrm{Zn}_{x}\left(\mathrm{PO}_{4}\right)_{3-2 x}\left(\mathrm{SO}_{4}\right)_{2 x}, 0 \leq x \leq 1$ (for $x_{\max }=1, \mathrm{PO}_{4}: \mathrm{SO}_{4}=1: 2$ ); for $\mathrm{NaZr}_{2-}$ ${ }_{x} \mathrm{Al}_{x}\left(\mathrm{PO}_{4}\right)_{3-x}\left(\mathrm{SO}_{4}\right)_{x}, 0 \leq x \leq 0.5$ (for $x_{\text {max }}=0.5, \mathrm{PO}_{4}: \mathrm{SO}_{4}=5: 1$ ); and for $\mathrm{NaZr}_{2-}$ ${ }_{x} \mathrm{Fe}_{x}\left(\mathrm{PO}_{4}\right)_{3-x}\left(\mathrm{SO}_{4}\right)_{x}, 0 \leq x \leq 1.25$ (for $x_{\max }=1.25, \mathrm{PO}_{4}: \mathrm{SO}_{4}=7: 5$ ). In the $\mathrm{NaZr}_{2-}$ ${ }_{x} \mathrm{Co}_{x}\left(\mathrm{PO}_{4}\right)_{3-2 x}\left(\mathrm{SO}_{4}\right)_{2 x}$ and $\mathrm{NaZr}_{2-x} \mathrm{Ni}_{x}\left(\mathrm{PO}_{4}\right)_{3-2 x}\left(\mathrm{SO}_{4}\right)_{2 x}$ series, foreign phases in small amounts appeared even for $x=0.5$.
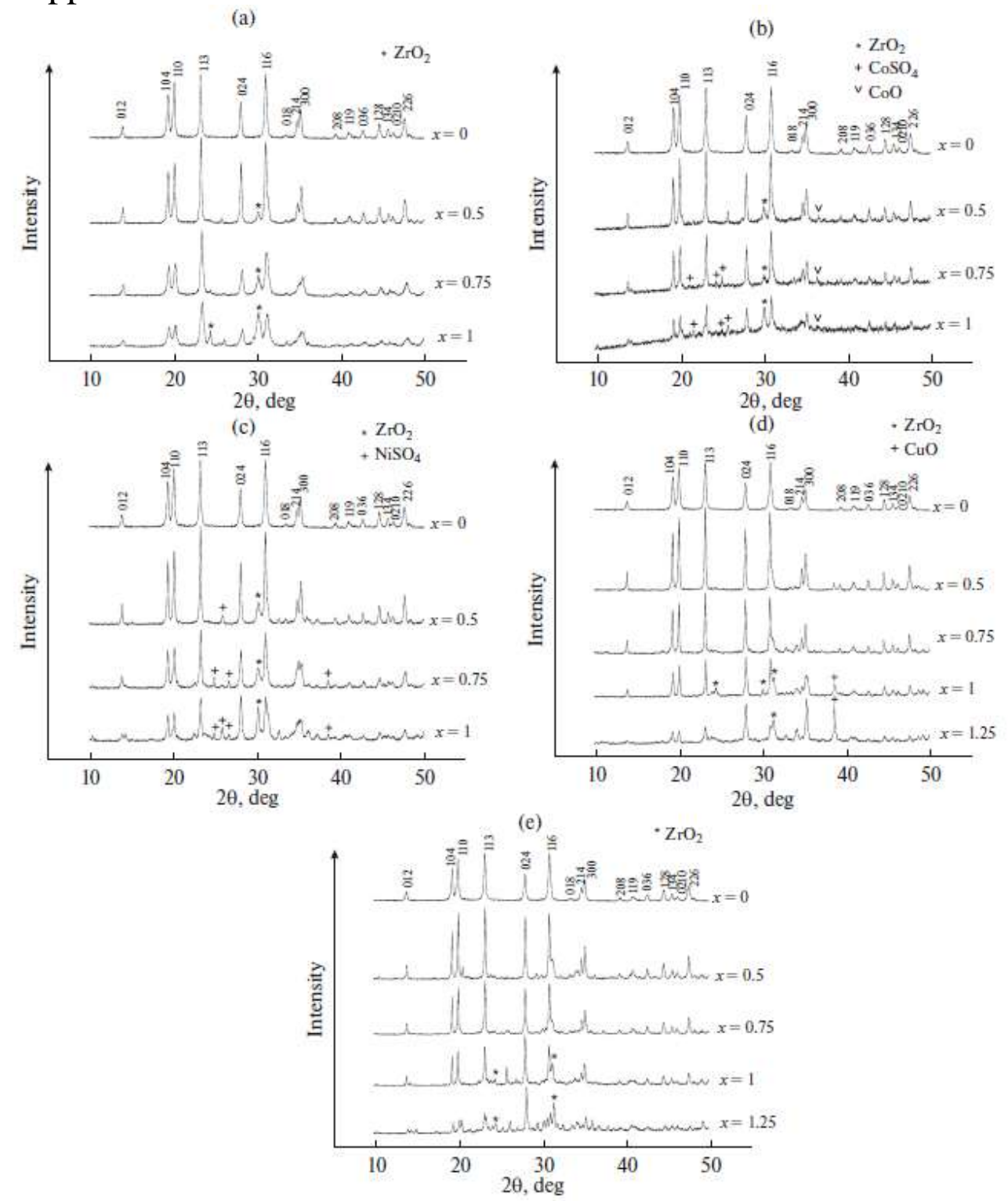

Fig. 7. XRD data. Phosphate-sulfates $\mathrm{NaZr}_{2-x} \mathrm{~B}_{x}\left(\mathrm{PO}_{4}\right)_{3-2 x}\left(\mathrm{SO}_{4}\right)_{2 x}$ where $\mathrm{B}=(\mathrm{a}) \mathrm{Mg}$, (b) $\mathrm{Co}$, (c) $\mathrm{Ni}$, (d) $\mathrm{Cu}$, and (e) $\mathrm{Zn}$ after annealingat $700^{\circ} \mathrm{C}$.

The resulting solid solutions crystallized, as expected, in $\mathrm{NaZr}_{2}\left(\mathrm{PO}_{4}\right)_{3}$ type structure, space group $R \overline{3} c$ (an analogue of $\mathrm{NaZr}_{2}\left(\mathrm{PO}_{4}\right)_{3}$ [13]).

Calculated unit cell parameters are listed in Table 1.

Table 1. Unit cell parameters of phosphate-sulfates $\mathrm{NaZr}_{2-x} \mathrm{R}_{x}\left(\mathrm{PO}_{4}\right)_{3-x}\left(\mathrm{SO}_{4}\right)_{x}$ and $\mathrm{NaZr}_{2-x} \mathrm{~B}_{x}\left(\mathrm{PO}_{4}\right)_{3-2 x}\left(\mathrm{SO}_{4}\right)_{2 x}$. Space group $R \overline{3} \mathrm{c}$

\begin{tabular}{|c|c|c|c|c|}
\hline \multicolumn{2}{|c|}{ Состав } & \multirow{2}{*}{ a,$\AA$} & c,$\AA$ & $\mathrm{V}, \AA^{3}$ \\
\cline { 1 - 2 } $\mathrm{B}, \mathrm{R}$ & $\mathrm{x}$ & & & \\
\hline
\end{tabular}




\begin{tabular}{|c|c|c|c|c|}
\hline- & 0 & $8.822(8)$ & $22.814(0)$ & $1537.9(6)$ \\
\hline \multirow{3}{*}{$\mathrm{Mg}$} & 0.5 & $8.801(7)$ & $22.845(0)$ & $1532.6(9)$ \\
\cline { 2 - 5 } & 0.75 & $8.765(4)$ & $22.772(8)$ & $1515.2(7)$ \\
\hline \multirow{3}{*}{$\mathrm{Co}$} & 0.5 & $8.809(8)$ & $22.896(1)$ & $1538.9(5)$ \\
\cline { 2 - 5 } & 0.75 & $8.804(2)$ & $22.855(0)$ & $1534.2(3)$ \\
\hline \multirow{3}{*}{$\mathrm{Ni}$} & 0.5 & $8.809(2)$ & $22.857(3)$ & $1536.1(3)$ \\
\cline { 2 - 5 } & 0.75 & $8.792(1)$ & $22.877(5)$ & $1531.5(3)$ \\
\hline \multirow{4}{*}{$\mathrm{Cu}$} & 0.5 & $8.817(2)$ & $22.881(2)$ & $1540.5(3)$ \\
\cline { 2 - 5 } & 0.75 & $8.808(1)$ & $22.865(2)$ & $1536.2(8)$ \\
\cline { 2 - 5 } & 1 & $8.808(2)$ & $22.819(2)$ & $1533.2(2)$ \\
\hline \multirow{3}{*}{$\mathrm{Zn}$} & 0.5 & $8.810(4)$ & $22.856(1)$ & $1536.4(7)$ \\
\cline { 2 - 5 } & 0.75 & $8.814(9)$ & $22.854(3)$ & $1537.9(2)$ \\
\cline { 2 - 5 } & 1 & $8.818(6)$ & $22.846(6)$ & $1538.6(9)$ \\
\hline \multirow{2}{*}{$\mathrm{Al}$} & 0.5 & $8.784(4)$ & $22.798(1)$ & $1523.5(4)$ \\
\hline \multirow{3}{*}{$\mathrm{Fe}$} & 0.5 & $8.764(0)$ & $22.728(1)$ & $1511.8(1)$ \\
\cline { 2 - 5 } & 0.75 & $8.786(3)$ & $22.710(4)$ & $1518.3(3)$ \\
\cline { 2 - 5 } & 1 & $8.728(5)$ & $22.726(7)$ & $1499.5(0)$ \\
\cline { 2 - 5 } & 1.25 & $8.713(3)$ & $22.644(4)$ & $1488.8(7)$ \\
\hline
\end{tabular}

Most of the series feature a reduction in unit cell volumes with increasing sulfate group content in the compound. The exclusion is the Zn-containing phosphate-sulfate series. This may be explained by the large ionic radius of zinc compared to that of zirconium.

We failed to find any correlation between the unit cell parameters and ionic radii of framework cations. This might be due to the effect of sample preparation conditions on the unit cell parameters just as described elsewhere [36]. This should be taken into account in subsequent studies of large series of compounds of the NZP family.

Our next step was a high-temperature X-ray diffraction study of thermal expansion in one phosphate- sulfate with a high sulfur content in the tetrahedral anion $\left(\mathrm{PO}_{4}: \mathrm{SO}_{4}=1: 1\right)$, namely, $\mathrm{NaZr}_{1.25} \mathrm{Cu}_{0.75}\left(\mathrm{PO}_{4}\right)_{1.5}\left(\mathrm{SO}_{4}\right)_{1.5}$, a representative of the $\mathrm{NaZr}_{2-x} \mathrm{Cu}_{x}\left(\mathrm{PO}_{4}\right)_{3-2 x}\left(\mathrm{SO}_{4}\right)_{2 x}(x=0.75)$ series in the range $25-700^{\circ} \mathrm{C}$ in $100^{\circ} \mathrm{C}$ steps (Fig. 9). The $\mathrm{Cu}^{2+}$ and $\mathrm{Zr}^{4+}$ radii in coordination polyhedra with $\mathrm{CN}=6$ have close values: $r\left(\mathrm{Cu}^{2+}\right)=0.073 \mathrm{~nm}$, and $r\left(\mathrm{Zr}^{4+}\right)=0.072 \mathrm{~nm}$. 
(a)

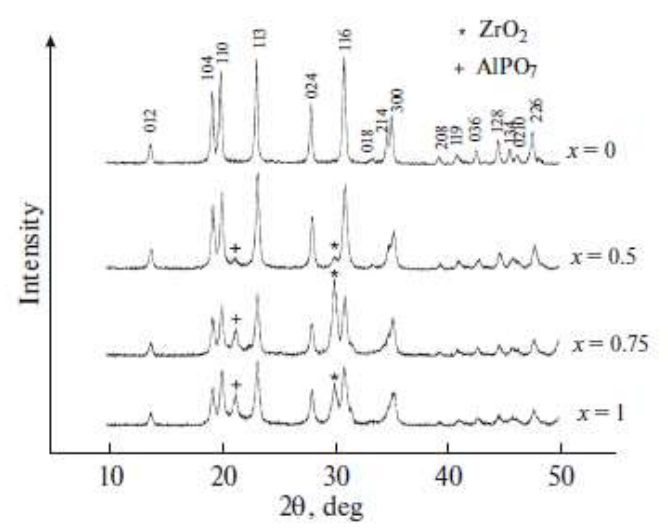

(b)

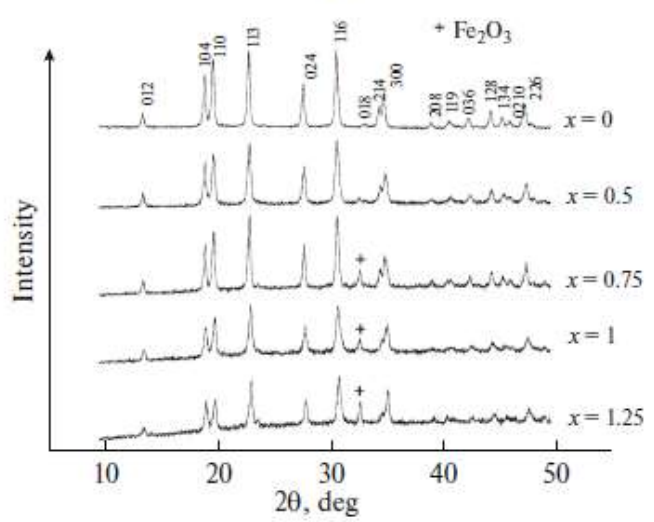

Fig. 8. XRD data. Phosphate-sulfates $\mathrm{NaZr}_{2-x} \mathrm{R}_{x}\left(\mathrm{PO}_{4}\right)_{3-x}\left(\mathrm{SO}_{4}\right)_{x}$ where $\mathrm{R}=$ (a) $\mathrm{Al}$ and (b) Fe after annealing at $700^{\circ} \mathrm{C}$.

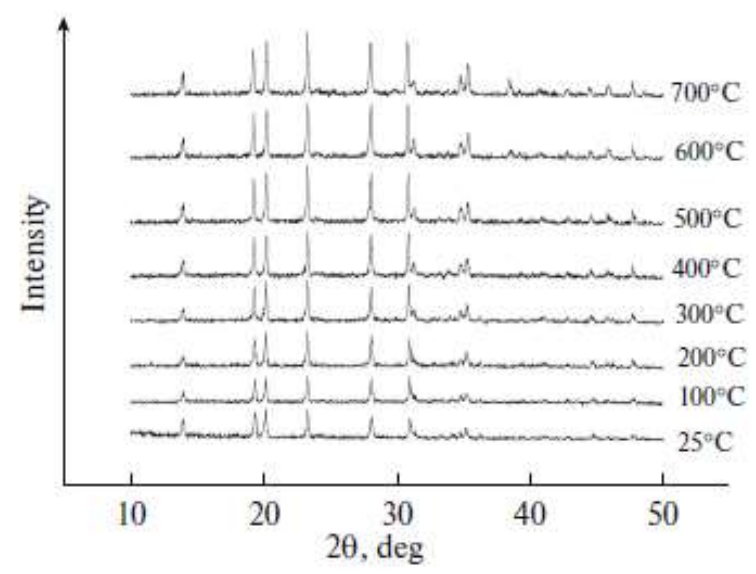

Fig. 9. High-temperature $\mathrm{X}$-ray diffraction data. Phosphate-sulfate $\mathrm{NaZr}_{1.25} \mathrm{Cu}_{0.75}\left(\mathrm{PO}_{4}\right)_{1.5}\left(\mathrm{SO}_{4}\right)_{1.5}$ at $25-700^{\circ} \mathrm{C}$.

We calculated $\mathrm{NaZr}_{1.25} \mathrm{Cu}_{0.75}\left(\mathrm{PO}_{4}\right)_{1.5}\left(\mathrm{SO}_{4}\right)_{1.5}$ unit cell parameters at 25, 100, $200,300,400,500,600$, and $700^{\circ} \mathrm{C}$. They are plotted as a function of temperature in Fig. 10.

Axial and average thermal expansion coefficients and thermal expansion anisotropy had the following values: $\alpha_{\mathrm{a}}=-5.40 \times 10^{-6}{ }^{\circ} \mathrm{C}^{-1}, \alpha_{\mathrm{c}}=18.88 \times 10^{-6}{ }^{\circ} \mathrm{C}^{-1}$, $\alpha_{\text {avg }}=2.69 \times 10^{-6}{ }^{\circ} \mathrm{C}^{-1}$, and $\Delta \alpha=24.28 \times 10^{-6}{ }^{\circ} \mathrm{C}^{-1}$. Comparison with respective values for $\mathrm{AZr}_{2}\left(\mathrm{PO}_{4}\right)_{3}(\mathrm{~A}=\mathrm{Na}$ [15], $\mathrm{K}$ [37], $\mathrm{Rb}$ [38], and Cs [38]) isostructural phosphates (Fig. 11) shows an obvious decrease in these characteristics upon the replacement of phosphorus $\left(r\left(\mathrm{P}^{5+}\right)=0.017 \mathrm{~nm}\right)$ by sulfur $\left(r\left(\mathrm{~S}^{6+}\right)=0.012 \mathrm{~nm}\right)$ in the $\mathrm{XO}_{4}$ group (for $\mathrm{NaZr}_{2}\left(\mathrm{PO}_{4}\right)_{3}, \alpha_{\mathrm{a}}=-6.42 \times 10^{-6}{ }^{\circ} \mathrm{C}^{-1}, \alpha_{\mathrm{c}}=25.5 \times 10^{-6}{ }^{\circ} \mathrm{C}^{-1}, \alpha_{\text {avg }}=$ $4.22 \times 10^{-6}{ }^{\circ} \mathrm{C}^{-1}$, and $\Delta \alpha=31.92 \times 10^{-6}{ }^{\circ} \mathrm{C}^{-1}$ [15]). Thus, the principle of reducing thermal expansion parameters via decreasing cationic radius in the $\mathrm{XO}_{4}$ anionic tetrahedron holds. In the future, it is necessary to verify the implementation of this principle for other prepared and characterized compounds. 

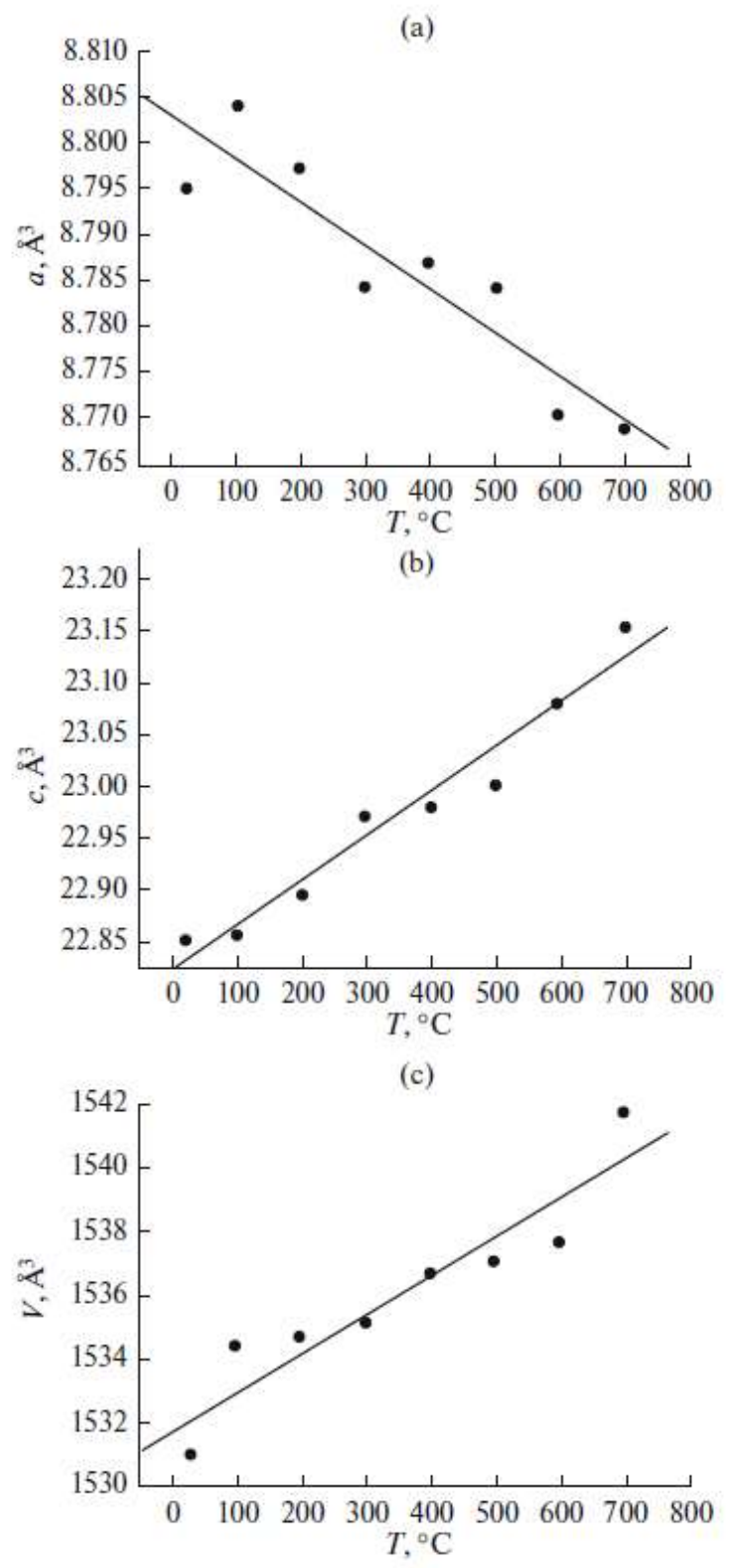

Fig. 10. Unit cell parameters $a, c$, and $V$ of $\mathrm{NaZr}_{1.25} \mathrm{Cu}_{0.75}\left(\mathrm{PO}_{4}\right)_{1.5}\left(\mathrm{SO}_{4}\right)_{1.5}$ versus temperature.

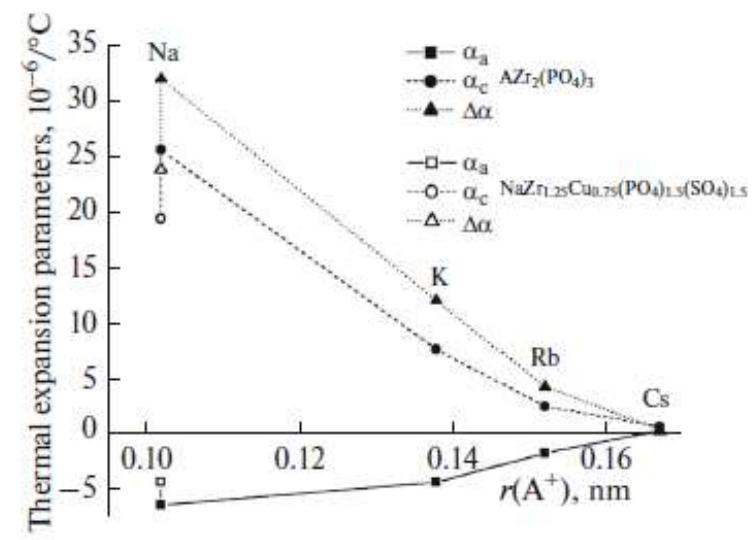

Fig. 11. Thermal expansion parameters of $\mathrm{AZr}_{2}\left(\mathrm{PO}_{4}\right)_{3}$ phosphates $(\mathrm{A}=\mathrm{Na}$ [15], $\mathrm{K}$ [37], $\mathrm{Rb}$ [38], and $\mathrm{Cs}$ [38]) and phosphate-sulfate $\mathrm{NaZr}_{1.25} \mathrm{Cu}_{0.75}\left(\mathrm{PO}_{4}\right)_{1.5}\left(\mathrm{SO}_{4}\right)_{1.5}$. 


\section{CONCLUSIONS}

We have prepared NZP compounds having a mixed phosphate-sulfate anionic part using various metal cations $(\mathrm{Mg}, \mathrm{Co}, \mathrm{Ni}, \mathrm{Cu}, \mathrm{Zn}, \mathrm{Al}$, and $\mathrm{Fe}$ ) for balancing the framework charge change. Heterovalent isomorphism was implemented, i.e., replacement of cation-cation and cation-anion pairs having equal total charges. We have found that the maximal possible content of sulfate group $\left(\mathrm{PO}_{4}: \mathrm{SO}_{4}=1\right.$ : 2 ) is attainable with $\mathrm{Cu}$ or $\mathrm{Zn}$ framework cations.

Phosphate-sulfate $\mathrm{NaZr}_{1.25} \mathrm{Cu}_{0.75}\left(\mathrm{PO}_{4}\right)_{1.5}\left(\mathrm{SO}_{4}\right)_{1.5}\left(\mathrm{PO}_{4}: \mathrm{SO}_{4}=1: 1\right)$ served us as an example to study the effect of isomorphous substitution in the anionic part of the NZP framework on the thermal expansion of the material. As probed by hightemperature $\mathrm{X}$-ray diffraction, this phosphate-sulfate belongs to materials that experience moderate expansion $\left(2 \times 10^{-6} \leq \alpha_{\text {avg }} \leq 8 \times 10^{-6}{ }^{\circ} \mathrm{C}^{-1}\right)$ upon heating. In comparison of the thermal expansion characteristics of the studied phosphatesulfate with the respective values for $\mathrm{NaZr}_{2}\left(\mathrm{PO}_{4}\right)_{3}$, a noticeable reduction is observed in the absolute values of linear thermal expansion coefficients and thermal expansion anisotropy $\left(\alpha_{a}\right.$ by $16 \%, \alpha_{c}$ by $26 \%, \Delta \alpha$ by $24 \%$ ). Thus, we may conclude that the insertion of a sulfate group into an NZP compound promotes a reduction in thermal expansion characteristics and can serve as a way to modify these characteristics. Thermal expansion in other phosphate-sulfates of those prepared and characterized in this study will be the subject of further research.

\section{ACKNOWLEDGMENTS}

This study was supported by the Russian Scientific Foundation (project no. 1613-10464 "Advanced ceramic like mineral materials with improved and adjustable service characteristics: design, synthesis, study" 2016-2018.

\section{REFERENCES}

1. Y. Hirata, Ceram. Int. 41, 1145 (2015).

2. P. Oikonomou, Ch. Dedeloudis, C. J. Stournaras, and Ch. Ftikos, J. Eur. Ceram. Soc. 27, 1253 (2007).

3. A. I. Orlova, S. G. Samoilov, G. N. Kazantsev, et al., Crystallogr. Repts 54, 431 (2009).

4. T. Isobe, T. Umezome, Y. Kameshima, et al., Mater. Res. Bull. 44, 2045 (2009).

5. A. I. Orlova, S. A. Khainakov, A. S. Ivanova, et al., Kristallografiya 58, 64 (2013).

6. J. Alamo, Solid State Ionics 63-65, 547 (1993).

7. A. I. Orlova, Radiochem. 44, 423 (2002).

8. E. Breval, H. A. McKinstry, and D. K. Agrawal, J. Mater. Sci. 35, 3359 (2000).

9. T. Oota and I. Yamai, J. Am. Chem. Soc. 69, 1 (1986).

10. G. E. Lenain, H. A. McKinstry, J. Alamo, and D. K. Agrawal, J. Mater. Sci. 22, 17 (1987).

11. J. L. Rodrigo and J. Alamo, Mater. Res. Bull. 26, 475(1991).

12. D. Tailor, Br. Ceram. Trans. 90 (2), 64 (1991).

13. L. Hagman and P. Kierkegaard, Acta Chem. Scand. 22, 1822 (1822).

14. A. I. Orlova and A. K. Korittseva, Crystallogr. Repts 49, 724 (2004). 
15. G. E. Lenain, H. A. McKinstry, S. Y. Limaye, and D. A. Woodward, Mater. Res. Bull. 19, 1451 (1984).

16. Ye. V. Bortsova, A. K. Koryttseva, A. I. Orlova, et al., J. Alloys Compd. 475, 74 (2009).

17. A. I. Orlova, A. K. Korittseva, Ye. V. Lipatova, et al., J. Mater. Sci. 40, 2741 (2005).

18. V. Yu. Volgutov and A. I. Orlova, Crystallogr. Repts 60, 721 (2015).

19. S. Y. Limaye, D. K. Agrawal, R. Roy, and Y. Mehrotra, J. Mater. Sci. 26, 93 (1991).

20. A. I. Orlova, A. K. Korittseva, Ye. V. Bortsova, et al., Crystallogr. Repts 51, 357 (2006).

21. G. Rambabu, RaoK. Koteswara, N. Anantharamulu, et al., J. Mater. Sci. 42, 3613 (2007).

22. N. Anantharamulu, RaoK. Koteswara, M. Vithal, and G. Prasad, J. Alloys Compd. 479, 684 (2009).

23. G. Buvaneswari, KuttyK. V. Govindan, and U. V. Varadaraju, Mater. Res. Bull. 39, 475 (2004).

24. M. P. Carrasco, M. C. Guillem, and J. Alamo, Mater. Res. Bull. 29, 817 (1994).

25. KuttyK. V. Govindan, R. Asuvathraman, C. K. Mathews, and U. V. Varadaraju, Mater. Res. Bull.

29, 1009 (1994).

26. D. A. Woodcock, P. Lightfoot, and C. Ritter, Chem. Commun., No. 1, 107 (1998).

27. P. Lightfoot, D. A. Woodcock, J. D. Jorgensen, and S. Short, Int. J. Inorg. Mater 1, 53 (1999).

28. M. Alami, R. Brochu, J. L. Soubeyroux, et al., J. Solid State Chem. 90, 185 (1991).

29. R. Brochu, M. Louer, M. Alami, et al., Mater. Res. Bull. 32, 113 (1997).

30. I. Yamai, T. Ota, and P. Jin, J. Ceram. Soc. Jpn. 96, 1019 (1988).

31. J. Alamo and R. Roy, J. Solid State Chem. 51, 270(1984).

32. Y. Piffard, A. Verbaere, and M. Kinoshita, J. Solid State Chem. 71, 121 (1987).

33. G. Blasse, Y. Piffard, and L. Struye, Chem. Phys. Lett. 147, 514 (1988).

34. V. I. Pet'kov, A. S. Dmitrienko, M. V. Sukhanov, et al., Russ. J. Inorg. Chem. 61, 623 (2016).

35. J. Laugier and B. Bochu, LMGP Suite of Programs for the Interpretation of Xray Experiments, ENSP (Laboratoire des Materriaux et du Gernie Physique, France).

36. V. I. Pet'kov, A. I. Orlova, and O. V. Egor'kova, J. Struct. Chem. 37, 933 (1996).

37. T. Ota and I. Yamai, J. Ceram. Soc. Jpn. 95, 531 (1987).

38. E. Breval and D. K. Agrawal, Br. Ceram. Trans. 94 (1), 27 (1995). 